“Transfer” XIV: 1-2 (2019), pp. 182-201. ISSN: 1886-554

\title{
UNDISCIPLINABLE: \\ The Place of Translation StUdies WITHIN THE History OF INTERDISCIPLINARITY IN THE UNITED STATES
}

Spencer Hawkins (ORCID 0000-0001-8988-8162)

University of Notre Dame (U.S.A.)

Reception date: 30/04/2018; Acceptance date: 09/05/2018

\section{Introduction}

The modern explosion of academic specializations has not squelched, but fostered pluralistic, democratic approaches to interdisciplinary university teaching and research in the United States since around 1900 when administrators decisively rejected the authoritarian European approaches to education in favor of the German model, which presented the purpose of universities as training interpretive thinkers. But the German model developed in autocratic kingdoms, especially Prussia, and intellectual authority mimicked autocratic authority in its intolerance for rivalry. Over the decades of the twentieth century, the U.S. incarnation of the German model would have to become less feudal in its view of intellectual authority in order to find a place among free citizens, not as subjects. Interdisciplinarity has been key to expanding the variety of perspectives (gender, ethnic, linguistic-national, political) that could be expressed in U.S. university contexts.

Throughout the last century, translation questions have oriented both the methods and the goals of interdisciplinary work. Translation Studies is exemplary of pluralistic interdisciplinarity since it works across area studies disciplines as well as linguistics, anthropology, literary studies, among others. And yet other interdisciplinary fields have flourished at U.S. universities far more 
“Transfer” XIV: 1-2 (2019), pp. 182-201. ISSN: 1886-554

quickly and widely than Translation Studies has, perhaps because Americans are notoriously unskillful with foreign languages. The language learning deficit began around 1917, when many U.S. public schools cut whole foreign language programs during a short-lived, yet vigorous criminalization of German language instruction. The ban on German ended in 1919 with Meyer v. Nebraska, which denied the constitutionality of Nebraska's statutes against foreign language instruction generally. However, the stigma against foreign languages continued to impede children from learning them long after the Great War (Gordin 2015: 180-185). The extremely restrictive immigration quotas spanning 1924-1965 made the twentieth century a markedly monolingual one.

To compound the problem, after WWII, the rise of English as a global language and the growing conviction within the United States of its economic exceptionalism (fueled in the nineteenth century by massive profits from slave labor, successful industrialization, and the Gold Rush) further reduced the urgency for U.S. citizens to learn foreign languages. It is fitting that one of today's leading U.S.-based Translation Studies book series (Translation/Transnation, Princeton University Press) is focused on linguistic power imbalances since the economic dominance of global English is precisely what discourages U.S.-based scholars from devoting more resources to translation research and training.

Despite the marginalization of Translation Studies in the twentieth century, a number of translation programs have gained prominence in the twenty-first (Venuti 2016). This paper looks to past and present university practices for explanations of what has facilitated the spread of Translation Studies and what still hampers it. Beyond promoting interdisciplinary Translation Studies, this paper considers strategies for making both Translation Studies and translation itself more visible in a U.S. context. 
“Transfer” XIV: 1-2 (2019), pp. 182-201. ISSN: 1886-554

\section{Interdisciplinarity in the United States: a case of translatio studii}

Multidisciplinarity is as old as the plural in the name liberalia studia, often translated "Liberal Arts" - an educational model that integrates technical, artistic, and humanistic pursuits along with physical training. Medieval in nomenclature, the liberal arts ideal harkens back at least to Plato's Academy where mathematics was understood as a foundation for training in logic, ethics, physical sciences, and metaphysical speculation. The word liberalis signals the illiberalism of the term's origin: only those free (liberalis) from slavery or serfdom were worth educating in a well-rounded way. Fourteenth-century Florence saw a hysteron proteron in the justification for liberal arts: it was not that men received liberal education because they were free, but that a well-rounded, humanistic education could enhance the freedom specific to success in politics. Rhetorical training especially served upwardly mobile Florentine elites the same way it served Romans: by training them for careers that required effective political rhetoric and decision-making (Nauert 2006: 14-15). Because of its political career training purpose, the Renaissance educational model was less interdisciplinary, reducing the focus on abstract disciplines like logic and the natural sciences.

In the United States, around 1900, the concept of liberal education expanded, this time to encompass the burgeoning natural sciences. Given the more democratic political climate, it also took a decisive turn towards the classless ideal of liberalism: American educators translated the concept of liberal education from its old function of training the slave-holding or feudal elite into education for democratic citizenship. This revision is evident in Columbia University English Professor Brander Matthews' 1904 speech on "Literature in the New Century," where he calls for "the growth of the 
“Transfer” XIV: 1-2 (2019), pp. 182-201. ISSN: 1886-554

scientific spirit" in literary studies as the surest way to give up "an unwavering admiration for all the works of a great writer," all with the goal of "the final disappearance of the feudal organization in the world [and] of the belief in any superiority conferred by the accident of birth" (Matthews 1904: 518). Matthews saw interdisciplinary humanities as building on the success of national language movements, which would facilitate "cosmopolitan" learning about foreign languages and cultures and enhance the cause of democracy in the world. ${ }^{1}$ The interdisciplinary turn to "the scientific spirit" of inquiry for literary studies contributed to the mission, growth, and endurance of U.S. academic humanities departments in the twentieth century.

Turn-of-the-century American university administrators managed to revive the medieval ideal of multidisciplinary training by taking inspiration from a feudal kingdom on a delayed path towards nationhood: Prussia. American administrators were particularly inspired by the university reforms of the linguist-polymath Wilhelm von Humboldt at the University of Berlin. Perhaps the biggest difference between medieval education and late nineteenth-century German education was the German focus on the plurality of languages. The Humboldtian educational ideal combined a medieval mystical attitude towards humanized spirit (Geist), the Renaissance focus on the human, and the modern empirical study of languages. Despite a tendency to hierarchize languages according to the subtlety of thought that their literature displayed, Humboldt had a sophisticated view of linguistic change and diversity. His thinking

\footnotetext{
${ }^{1}$ Barbara Cassin asserts that wide reach - like national languages have- is necessary for a language to represent a culture publicly. She comments specifically on the failure of dialects to function in public contexts: "a language becomes a dialect when it can no longer be opposed to another language, when there are no longer several languages but a global language and local ways of speaking" (Cassin 2017: n.p.).
} 
“Transfer” XIV: 1-2 (2019), pp. 182-201. ISSN: 1886-554

anticipates post-structuralist rejection of the notion of national languages as stable systems:

Language, regarded in its real nature, is an enduring thing, and at every moment a transitory one. Even its maintenance by writing is always just an incomplete, mummy-like preservation, only needed again in attempting thereby to picture the living utterance. In itself it is no product (Ergon), but an activity (Energeia). Its true definition can therefore only be a genetic one. For it is the ever-repeated mental labour of making the articulated sound capable of expressing thought. (Humboldt 2000: §8)

Understanding and cultivating language's expressive power required Humboldt's firm commitment to Geisteswissenschaften, which established Germany's leading role in the emerging disciplines, like classical philology. Harvard administrators habitually visited the great nineteenth-century University of Berlin around the turn of the century. Hugo von Münsterberg, a philosopher recruited by William James to teach at Harvard, traveled to Berlin in 1903 and met with Kaiser Wilhelm II, as well as many academics and politicians (Bordogna 2008: 231).

But Münsterberg peddled his own theory that philosophy would unify the various branches of knowledge, an approach that other interdisciplinary innovators at Harvard found too doctrinaire. William James, for instance, much preferred philosopher Thomas Davidson's view of philosophy not as a discipline, but as a way of life that did not necessarily lead to scholarly output but rather militated against the strictures of whichever habits of mind restrict freethinking. In his eulogy to Davidson, rather than recognizing philosophy as the master discipline, James dubbed his philosopher friend "undisciplinable," a coinage that reverses the stigma of failure to commit to a discipline, by framing it instead as radical openness to insights from various perspectives. In James' words, "a few 
“Transfer” XIV: 1-2 (2019), pp. 182-201. ISSN: 1886-554

undisciplinables like Davidson [would be] infinitely more precious than a faculty-full of orderly routinists" (James 1987: 90). The sense is that, as Humboldt claimed about monolingualism, monodisciplinarity is a noxious blinder on thought.

Already around 1900, U.S. universities provided students more access to cross-disciplinary education than their European precursors. When Harvard president Charles William Eliot went to Europe to interview students and educators at the University of Berlin, one feature of the German system struck him as illiberal: the early tracking of students into vocational paths. Eliot advocated the "American idea of higher education as a formalized opportunity to rethink one's vocation and retool toward a different future" (Davidson 2017: 30). Cathy Davidson names her 2017 book after Eliot's treatise "The New Education" and advocates for an update to the U.S. university system. She calls for an education more intimately tied to real-world problem-solving, a resistance to unreflective technophilia, and - of course - greater state investment to offset growing costs and to resist the encroachment of corporate models that are not focused on reducing student financial burden.

Once the new university took form, Great Books programs emerged, and translation would play a prominent role in liberal education. Universities focused on world literature in translation, most prominently at the University of Chicago in 1930. Chicago President Robert Hutchins shifts his rhetoric from Brander's embrace of the scientific spirit in literary studies; for Chicago's core curriculum program, Hutchins confessed a conservative agenda to preserve the power of non-scientific insights from the past. Hutchins sought to reserve a place for aesthetic experience against the tide of the already dominant incentives of technologized capitalism.

The postwar period marked the definitive moment of democratization for U. S. universities. During WWII, Frankfurt School critical theorists and other German-speaking cultural theorists 
“Transfer” XIV: 1-2 (2019), pp. 182-201. ISSN: 1886-554

(including Ernst Cassirer, Hannah Arendt, Herbert Marcuse, Theodor Adorno, and Leo Spitzer) emigrated to the United States. Their work directly addressed the rise of fascism, and they in turn shaped the leftist political consciousness of postwar comparative literature programs. After the war, the G.I. Bill ended the narrow class profile of the university student. The enrollment of former servicemen from all socio-economic classes largely invalidated old, classist university admissions policies. It was not until the late 1960s, though, that new interdisciplinary programs like Black Studies emerge, and that women are first admitted to Ivy League universities.

In spite of democratization efforts, U.S. education would find new ways to remain de facto as restricted to the elite as its European forebears. After the expanded reach achieved in the 1970s, a new form of restriction arose in the ensuring decades: U.S became vastly more expensive than its European counterpart. Over the last decades of the twentieth century, largely in response to successes of the Civil Rights Movement, students from an even greater variety of backgrounds began attending universities. This new diversity helped justify the establishment of interdisciplinary cultural critical programs with regional (South East Asian, Near Eastern), ethnic (AfricanAmerican, Latinx), or linguistic (German, Russian) focuses that incorporated knowledge from traditional disciplines, such as history, sociology, and literary studies. The ethos of such interdisciplinary critical programs affected even Liberal Arts programs; many such department members take on politically "liberal" stances in the everyday sense of the word, or even radical ones (to the consternation of some university regents who continue manning the rear guard rhetorically, invest in military technology, and actively hamper campus protest activity).

The rising costs of attending university partly explains the massive increase in economics that outcompete humanistic interdisciplinary programs, unless these programs' faculties could not easily 
“Transfer” XIV: 1-2 (2019), pp. 182-201. ISSN: 1886-554

communicate to students, parents, and upper administrators how their programs train students for twenty-first-century careers. This is a self-presentation issue since Interdisciplinary Studies programs emerged precisely as a means of "addressing a complex problem that cannot be resolved using a disciplinary focus" (Augsburg 2009: 10). Tanya Augsburg argues that interdisciplinary degrees provide the most practical training for the changing economy. However, numerous Interdisciplinary Studies programs in the wake of the 2008 financial crisis closed, were merged with other departments, or were renamed because it was unclear to administrators what their purpose was. It was not only small, unprofitable programs that were closed, but also large, popular ones that were seen as competing for majors with other departments without offering training recognizable to those who did know the programs' regional reputations.

Interdisciplinary scholarship is in a similar bind as interdisciplinary teaching. Programs at University of Michigan, University of Minnesota, and Northeastern each sought to hire dozens of interdisciplinary scholars in the last decades (mostly in the natural sciences-which have become increasingly defining of the standards of interdisciplinary thinking). On the other hand, a 2013 study by the Cornell Higher Education Research Institute found that academics with interdisciplinary dissertations earned $\$ 1,700$ less on average than those with monodisciplinary ones (Graff 2015: 1-2). Work remains ahead to promote the value of interdisciplinary thought as a democratizing, problem-solving force-not just a form of dilettantism that evades easy evaluation.

Today, scholars working in Translation Studies are in a strong position to promote interdisciplinarity. In Sandra Bermann's 2009 ACLA Presidential Address, Bermann updates the case for interdisciplinarity in the context of our globally networked era by describing translation as paradigmatic of the educational task of comparative literature today. Bermann's speech advocates for translation and 
“Transfer” XIV: 1-2 (2019), pp. 182-201. ISSN: 1886-554

comparative literature as sites of interdepartmental collaboration on campuses: "As we move into the future of our polyglot planet, we can work in this and zone to broaden and deepen these conversations" (Bermann 2009: 444). Beyond Humboldt's case for the essence of culture revealed in the study of foreign languages, Bermann argues for translatorly worldliness not unlike the cosmopolitanism Matthews envisioned. ${ }^{2}$

One risk of advocating interdisciplinary work is to appear dismissive of disciplinary norms and their importance as evaluation criteria. Interdisciplinary collaborations require professors to adopt humility even in teacher-student interactions. As Cathy Davidson suggests: "We live in a time when the world's problems are of such magnitude that no one knows the answers. Yet in universities, we are still teaching as if we know. That's a deception" (Davidson 2017: 144). Perhaps the forces restricting interdisciplinarity at universities are the same as those that keep translation invisible: admitting ignorance is too risky in environments like universities where individual (or team) originality and mastery are highly rewarded. It is disturbing to reflect on one's shortcomings: when you rely on a translation of a text and do not know the source language, it is easier not to think about that distressing circumstance. And the more visible the text's translatedness, the greater the embarrassment. But for those exposed to the values of contemporary translation theory, curiosity about foreignness replaces embarrassment. In terms of German philosophical traditions, it may be time to move from Wittgenstein's cynical insight that only those who have already thought his thoughts will understand his Tractatus to Gadamer's hope that we have a chance to

\footnotetext{
2 Bermann explicitly compares linguistic decenteredness with the decentered disciplines: "[...] this search for a tertium comparationis - a universal language or set of meanings by which individual languages could be measured and aligned- has proved as fruitless as the search for the trunk of the disciplinary tree for comparative literature" (Bermann 2009, 442).
} 
“Transfer” XIV: 1-2 (2019), pp. 182-201. ISSN: 1886-554

understand something new whenever we are interrupted from the comforts of prior understanding. More visible translation practices and interdisciplinary education both promote these expansive types of learning.

\section{Translation Studies as Exemplary Interdiscipline}

Translation Studies crosses disciplines in two dimensions. First of all, U.S.-based Translation Studies works out of a similar network of fields as comparative literature; it has drawn for years now on continental philosophy, psychology, sociology, cultural studies, and anthropology. The second way in which Translation Studies crosses disciplines remains better developed outside of the United States, where it is focused on teaching the varied skills required of working translators. Like any "applied knowledge," translation practice requires multiple competences, such as foreign language competences, linguistic knowledge, rhetorical finesse, and cultural knowledge - and while these are not academic disciplines, they work with insights gleaned from linguistics, area studies, and history- in addition to the fields listed earlier.

Translation Studies is situated within both theoretical and practical problem areas, as an academic field that mostly describes a theoretical object in the United States and that mostly trains practitioners abroad. Like architecture, it is one of those professions that has a robust descriptive theory about it, but which serves defined practical ends. As the translation industry grows and changes, AngloAmerican translation theory ought to ask whether its prescriptive claims can be made relevant to aspiring practitioners.

While interdisciplinary programs have variable success in attaining necessary funding, some interdisciplinary initiatives attract impressive funding. This is clear in cases where data science, natural sciences, and humanistic ethics interpenetrate. For instance, the 
“Transfer” XIV: 1-2 (2019), pp. 182-201. ISSN: 1886-554

project "New Directions" received funding from multiple major U.S. government-sponsored organizations from NASA to the NEH. This initiative, focused on climate science, was one of the few to bridge the greatest gap between disciplines: that between the three superdisciplinary categories: humanistic, natural, and social sciences.

Translation theory and practice can combine these superdisciplines in several ways. Background in medical biology is essential to success in medical translation, and most Translation Studies requires a general understanding of two cultures - an echo of the ideal of cosmopolitanism endorsed by linguist and University of Berlin founder Wilhelm von Humboldt. If it can do so without sacrificing classical Kantian notions like "the autonomy of reason," Translation Studies might profit from incorporating methods of collaboration found in the social sciences; it is after all a research field perennially caught between disciplines, languages, and values. Especially tense is the difference in disciplinary attitude between the microeconomics that accompany translation industry training and the Marxist economics of cultural theory.

\section{A transdisciplinary synthesis: craft and critique}

While sites that purvey work and resource sharing like ProZ and SmartCAT could go further in promoting solidarity among translators and greater visibility for the translation industry, their focus on education and networking provide valuable models for the academic field of Translation Studies. Because translation involves moving between different cultural-linguistic contexts, and many successful translations are team translations, the field seems poised to learn from interdisciplinary innovations in teamwork. A recent case study on "the science of team-science" discusses an ambitious interdisciplinary project, the Transdisciplinary Tobacco Use Research Centers, sponsored by a number of U.S. federal public health-related 
“Transfer” XIV: 1-2 (2019), pp. 182-201. ISSN: 1886-554

departments and organizations. The aspirations of better research through "network techniques" have led the U.S. government to sponsor this research initiative for over ten years. Using this highprofile example, the study based on this initiative distinguishes between three degrees of "cross-disciplinary" working processes. A "multi-disciplinary" process means that researchers simply share their work with researchers from other fields, and all participants are thus aware of the broader scope of the problems that they are working on. "Interdisciplinary" processes require researchers to reflect on perspectives from other disciplines in their own research output.

Most pertinent to Translation Studies, "transdisciplinary" processes involve the gradual training of researchers in methods and concepts from other disciplines (Stokols et al. 2010: 474). This is the most time-intensive and thus the rarest form of cross-disciplinary work, but it would behoove Translation Studies to consider its advantages. It is no coincidence that the great advantage sought in the transdisciplinary work on tobacco use was the increased capacity for "translation of knowledge" between collaborators and eventually to non-specialist stakeholders (477). However, lack of concern for the role of interlingual and cultural translation in approaching such problems would hamper the reach of such collaborations. In the case of tobacco use research, no localizable theory is imaginable without considering linguistic and semiotic differences. Surely depictions of cowboys, women, or camels smoking cigarettes evoke different affects in different geographic contexts.

Translation Studies routinely surpasses mere interdisciplinary synthesis then when it aspires to the transdisciplinary ideal of translating forms of knowledge between visual semiotics, ethnography, psychology, philosophical theory, and linguistics - as well as responding to forms of knowledge deemed non-academic, such as activist work and investigative journalism. Translation work focused 
“Transfer” XIV: 1-2 (2019), pp. 182-201. ISSN: 1886-554

on social justice is already defining the field's direction today. ${ }^{3}$ Another way to expand our disciplinary scope is to notice every new type of difficulty in the translation process: childhood language acquisition, the margins of linguistic propositionality, and of course ever finer grained attention to the differences between the expressive resources of languages with different semantic histories.

The two strands are rarely tied in practice. Interdisciplinary initiatives, at least, rarely focus on the importance of Translation Studies to their goals. Yet interdisciplinary and transdisciplinary approaches are suited to address the predicaments of modern translation practice. In a talk delivered in 2011 at Utrecht University, called "Anchoring Transdisciplinarity through a Network of Networks," Romanian physicist and international advocate of transdisciplinarity Basarab Nicolescu argues that the lack of communication between scholars working in different languages is one of the main inhibitors to transdisciplinarity, and he advocates, "[forming] a database of major transdisciplinary texts (articles and, if possible, books) available in English, French, German, Portuguese and Spanish." Unfortunately, in his short talk, he makes no mention of the translation problems involved in such a project, not the least of which is the financial problem of supporting the labor of such a translation project. The very theory of collaboration across disciplines lacks the insights of translation theory in describing its central concerns.

Curriculum that explains the insecure translation economy is integral to any transdisciplinary discussion of translation. Modern history has tended towards the gradual increase in the insecurity of labor markets in many industries since early modern urbanization, but especially since the boom in web-based work advertisement platforms. This tendency certainly affects translation theory and practice: the adjunctification of intellectual labor in higher education

${ }^{3}$ To cite a few: (Camps 2011; Inghilleri 2012; Tachtiris 2017). 
“Transfer” XIV: 1-2 (2019), pp. 182-201. ISSN: 1886-554

often amounts to reduced support for individual researchers in all fields -especially for fields not involved in producing tech deliverables or Yahoo news-worthy statistics. Meanwhile, translation practice has also responded to the Internet age in a way that facilitates the distribution of small, discrete translation assignments through online translation sites, while making it harder to establish an independent client base since the managing sites maintain policies that require all communication between clients and translators to occur through the translation company.

The state of the translation industry is on clearest display at online translation industry meetings. On September 20, 2016, Proz.com held a webinar called, the 2016 Virtual Conference for International Translation Day, where the site hosted online presentations by established translators in various subfields. Legal translator and legal counselor Sue Leschen's webinar, "Why don't translators and interpreters know how to run businesses?" advocated embracing the market's insecurity through the identity of a "digital nomad," negotiating fees, and "diversifying" projects to include language teaching, cultural consultancy work, relocation consultancy, and editing. Translator and translation training entrepreneur Claudia Brauer's talk "What the heck is the 'uberization' of translators \& interpreters?" also addressed the insecurity of translation labor in the Internet age (Brauer 2016). She spoke about how translation has joined the "sharing economy," where the "middleman is cut out" and "those who take control of the customer interface are the ones to gain." Like "ride-sharing" on Uber and "house-sharing" on AirBNB, translation (and tutoring, by the way) has become a peer-to-peer transaction where apps and websites have lowered prices and promise, "a safe, more reliable, convenient, and affordable way to get from point A to point B." Claiming that translation clients expect the same, she argues that translators' only chance for "survival" in this market is "to become an entrepreneur" and "budget for education" in 
“Transfer” XIV: 1-2 (2019), pp. 182-201. ISSN: 1886-554

the latest technologies pertinent to efficient translation (such as the latest machine-aided translation tools), efficient capture of a market (such as working with multiple sites and apps), and ultimately perhaps working one's way up to a management position.

Traditional humanities education instills an aversion to everything petit bourgeois, including these presenters' pragmatic call to participate in an insecure labor market with the hope of becoming a rare exception and taking advantage of that system. Yet translation - with its now notorious invisibility - is even more exemplary than academia of this trend in so many markets. Venuti's call to make translation visible still feels especially pertinent today when only a few privileged translators are in a position to engage in visible translation. When a translation must occur on the "back end" and pass as a quietly humming node in a network, translation theorists have their work cut out for them justifying the utility of making translation visible.

There are few possibilities available to subvert market forces, but at the very least cultural criticism exposes the forces involved: the supremacy of languages, like English, associated with wealthy national economies results in the marginalization of translation in general as a profitable economic activity. Communicating in English in the first place will generally lead to faster profit than rendering messages into or out of English because acquiring English language skills have become the entry point investment for participation in most labor markets.

In spite of these aversive realities, Translation Studies will thrive in the twenty-first century if it takes the form of rigorous training both in translation strategy and in cultural criticism. Those who excel at both might become the sort of "undisciplinables" that William James called for. Ideally we translation theorists will have the skills and imagination to navigate the precarious translation market in the entrepreneurial ways described in the ProZ seminars, but 
“Transfer” XIV: 1-2 (2019), pp. 182-201. ISSN: 1886-554

hopefully the work would not stop there. We can also understand translation as a site where humanistic problems and economic ones meet. The visibility of translation labor can be iconic for the visibility of so much labor that extractive industries thrive on concealing from view. Navigating deftly between languages requires a mind more inclined to pursue liberation from habit than merely to master disciplinary norms or best translation practices. When translators' mental flexibility is guided by historical consciousness, then we can best develop and teach provisional norms that make translation itself a site for learning about differential power as it manifests across linguistic differences.

\section{Works Cited}

AUGSBURG, Tanya. (2009). The Politics of Interdisciplinary Studies: Essays on Transformations in American. Jefferson, N.C.: McFarland.

BERMANN, Sandra. (2009). "Working in the And Zone: Comparative Literature and Translation." Comparative Literature 61 (4): 432-46. $\quad<<$ https://doi.org/10.1215/00104124-2009-025>> (Last access: June, 6, 2018).

BLUMENBERG, Hans. (2010). Paradigms for a Metaphorology. Ithaca N.Y.: Cornell University Press; Cornell University Library.

BORDOGNA, Francesca. (2008). William James at the Boundaries: Philosophy, Science, and the Geography of Knowledge. Chicago: University of Chicago Press.

BRAUER, Claudia. (2016). "What the Heck Is the 'Uberization' of Translators \& Interpreters?" presented at the ProZ.com 2016 virtual conference for International Translation Day, September 20. 
“Transfer” XIV: 1-2 (2019), pp. 182-201. ISSN: 1886-554

$<<$ https://www.proz.com/virtualconferences/697/program/11437 >>. June, 6, 2018.

CAMPS, Assumpta. (2011). "'A mitad de camino entre aquí y allá, en medio de quién sabe dónde': Traducir la/desde la frontera." MonTI: Monografías de traducción e interpretación, no. 3: 337354.

CASSIN, Barbara. (2017). "The power of bilingualism: Interview with Barbara Cassin, French philosopher and philologist - Frontpage - e-flux conversations".

$<<$ https://conversations.e-flux.com/t/the-power-ofbilingualism-interview-with-barbara-cassin-french-philosopherand-philologist/6252>>. (Last access: June, 6, 2018).

DAVIDSON, Cathy N. (2017). The New Education: How to Revolutionize the University to Prepare Students for a World In Flux. 1 edition. New York: Basic Books.

GADAMER, Hans-Georg. (2013). Truth and Method. London-New YorkSydney-New Delhi: Bloomsbury Academic.

GRAFF, Harvey J. (2015). Undisciplining Knowledge: Interdisciplinarity in the Twentieth Century. Baltimore: Johns Hopkins University Press.

GORDIN, Michael D. (2015). Scientific Babel: How Science was Done before and after Global English. Chicago: University of Chicago Press.

HUMBOLDT, Wilhelm von. (2000). Humboldt: "On Language": On the Diversity of Human Language Construction and Its Influence on the Mental Development of the Human Species. Edited by Michael Losonsky. Translated by Peter Heath. $2^{\text {nd }}$ edition. New York: Cambridge University Press.

INGHILLERI, Moira. (2012). Interpreting Justice: Ethics, Politics and Language. 1 edition. New York: Routledge.

JAMES, William. (1987). "Thomas Davidson: Individualist.” In: Essays, Comments, and Reviews. Cambridge, Mass.: Harvard Un. Press. 
“Transfer” XIV: 1-2 (2019), pp. 182-201. ISSN: 1886-554

LAPLANCHE, Jean. (1985). Life and Death in Psychoanalysis. Translated by Jeffrey Mehlman. Reprint edition. Baltimore: Johns Hopkins University Press.

MATTHEWS, Brander. (1904). "Literature in the New Century." The North American Review 179 (575): 513-25.

NAUERT, Charles G. (2006). Humanism and the Culture of Renaissance Europe. Cambridge, Mass.: Cambridge University Press.

STOKELS, Daniel; Kara L. Hall; Richard P. Moser; Annie X. Feng; Shalini Misra, and Brandie K. Taylor. (2010). "Cross-Disciplinary Team Science Initiatives: Research, Training, and Translation.” In: The Oxford Handbook of Interdisciplinarity, edited by Robert Frodeman, 471-81. Oxford Handbooks. Oxford: OUP Oxford. $<<$ http://search.ebscohost.com/login.aspx?direct=true\&db=nle bk\&AN=439722\&site=eds-live $>>$. June, 6, 2018.

TACHTIRIS, Corine. (2017). “Giving Voice: Translating Speech and Silence in Frieda Ekotto's Don't Whisper Too Much Corine Tachtiris." Translation Review 98 (1): 49-64.

<<https://doi.org/10.1080/07374836.2017.1305925 >>. (Last access: June, 6, 2018).

VENUTI, Lawrence. (2008). The Translator's Invisibility: A History of Translation. London; New York: Routledge.

. ed. (2016). Teaching Translation: Programs, Courses, Pedagogies. 1 edition. London; New York: Routledge.

\begin{abstract}
:
Interdisciplinarity at U.S. universities goes back at least to the turn of the nineteenth century. Whether interdisciplinary programs aim to increase integration with the natural sciences or to set up a counterforce to the intellectual authority of the sciences, thinking
\end{abstract}


“Transfer” XIV: 1-2 (2019), pp. 182-201. ISSN: 1886-554

across linguistic differences has always been at the heart of interdisciplinary pursuits in the United States. As Translation Studies grows in prominence at US institutions, the challenges of balancing theoretical concerns and technical training is one among a slew of concerns for this interdiscipline ever in the making. An avid theorist of university reform, philosopher William James provides an antidote to any deadening caricature of foreign texts' untranslatability with his notion of the "undisciplinable" thinker who perpetually turns to new sources in order to overcome old habits of mind, to achieve new experiences, and to produce more democratic forms of expression.

Key words: Transdisciplinarity, Education for Democracy, History of American Universities, Translation Industry

\section{INDISCIPLINABLE: \\ EL LUgar DE LA Traductología en LA Historia DE LA INTERdis- CIPLINARIEDAD EN LOS ESTADOS UNIDOS}

\section{Resumen:}

La interdisciplinariedad en las universidades de EE. UU. se remonta, al menos, a finales del siglo XIX. Ya sea que los programas interdisciplinarios tengan como objetivo incrementar la integración con las ciencias naturales o bien establecer una fuerza contraria a la autoridad intelectual de las ciencias, pensar a través de las diferencias lingüísticas siempre ha estado en el corazón de las actividades interdisciplinarias en los Estados Unidos. A medida que los Estudios de traducción cobran importancia en las instituciones de EE. UU., los desafíos que plantea el hecho de equilibrar las preocupaciones teóricas y la capacitación técnica son una de las preocupaciones que surgen en esta interdisciplina. Ávido teórico de la reforma 
“Transfer” XIV: 1-2 (2019), pp. 182-201. ISSN: 1886-554

universitaria, el filósofo William James proporciona un antídoto contra cualquier caricatura amortiguadora de la intraducibilidad de textos extranjeros con su noción del pensador "indisciplinable" que recurre perpetuamente a nuevas fuentes para superar viejos hábitos mentales, para lograr nuevas experiencias y para producir formas de expresión más democráticas.

Palabras clave:

Transdisciplinariedad, Educación para democracia, Industria de la traducción, Historia de la universidad en Estados Unidos 